\title{
Water Quality Changes during Riverbank Filtration in Budapest, Hungary
}

\author{
Zsuzsanna Nagy-Kovács ${ }^{1, *}$, János Davidesz ${ }^{1}$, Katalin Czihat-Mártonné ${ }^{1}$, Gábor Till ${ }^{1}$, \\ Ernő Fleit ${ }^{1}$ and Thomas Grischek ${ }^{2}$ \\ 1 Budapest Waterworks Ltd, Budapest H-1138, Hungary; janos.davidesz@vizmuvek.hu (J.D.); \\ katalin.martonne@vizmuvek.hu (K.C.-M.); gabor.till@vizmuvek.hu (G.T.); erno.fleit@vizmuvek.hu (E.F.) \\ 2 Division of Water Sciences, University of Applied Sciences Dresden, D-01069 Dresden, Germany; \\ thomas.grischek@htw-dresden.de \\ * Correspondence: zsuzsanna.nagy-kovacs@vizmuvek.hu
}

Received: 19 October 2018; Accepted: 6 February 2019; Published: 11 February 2019

\begin{abstract}
The paper gives an overview on the changes in water quality during riverbank filtration (RBF) in Budapest. As water from the Danube River is of high quality, no problems occur during regular operation of RBF systems. Additionally, water quality improved through the past three decades due to the implementation of communal wastewater treatment plants and the decline of extensive use of artificial fertilizers in agriculture. Algae counts are used as tracer indicators to identify input of surface water into wells and to make decisions regarding shutdowns during floods. RBF systems have a high buffering capacity and resistance against accidental spills of contaminants in the river, which was proven during the red mud spill in October 2010. The removal rate of microorganisms was between $1.5 \log$ and $3.5 \log$ efficiency and is in the same order as for other RBF sites worldwide.
\end{abstract}

Keywords: riverbank filtration; water quality; organic carbon; nitrate; heavy metals; microorganisms

\section{Introduction}

Riverbank filtration (RBF) is a widely used natural water treatment process where, by definition, at least $50 \%$ of treated water must originate from surface water. It has been observed that the surface water source, the hydrogeological characteristics of the aquifer, the protected watershed area and the particularities of production play an important role on the quality of the produced water [1-3].

RBF offers many advantages concerning improvement of water quality. This type of ecosystem service is used in many watersheds globally, including India, China, USA and Germany. RBF along the Danube River has been used for water supply in Budapest for over 150 years [4]. Due to the high quality of the Danube River water and favorable hydrogeological conditions at the Szentendre Island upstream of the city of Budapest, no post-treatment except disinfection is required after RBF processes. This unique situation enables us to study long-term trends in the characteristics of water quality parameters.

The focus is set on basic water quality parameters to describe microbiologically mediated reactions, physical sorption and mixing processes during RBF and the resulting attenuation of pollutants. Spatial changes in redox potential conditions were studied in RBF processes in Berlin, where it has been found that temperature variation strongly influenced the efficacy of microbial removal processes [5].

The vulnerability of RBF processes to climate change has been discussed in prior studies concentrating on oxic/aerated and anoxic conditions of the aquifer layers [6]. Redox conditions are profoundly affected by both microbiologically mediated pathways of nitrogen transformations (nitrification and denitrification) and physicochemical sorption processes and phase equilibria [7]. 
Local redox conditions, however, can only be indirectly controlled in the aquifer by the operator (i.e., pumping rates). In spite of the improvements in traditional water quality parameters, concerns arise regarding the microbial parameters of the Danube both upstream [8] and downstream of Budapest [9] related to the increasing incidence and severity of extremities.

The aim of this study is to give an overview regarding the efficiency of RBF processes. The basic concept is to analyze physical, chemical, microbiological and biological parameters and highlight existing connections. Challenges include seasonal variations in river water quality, floods, droughts, industrial and agricultural pollutant input variations. Therefore, it is important to consider water quality parameters which can be determined at a high number, high frequency and at low cost. Also, it is important to determine how these measurements can improve the level of service by faster and established interventions, lower disinfectant concentration and effective operational strategies.

\section{Materials and Methods}

\subsection{Site Description}

As the efficiency of RBF is site specific and the water quality changes are affected by many other factors besides source water quality, e.g., water level changes, travel times of bank filtrate, pumping regime of wells, etc., a large dataset is required to be able to determine reliable operational methodology. In this paper, data from the period 2006 to 2017 from a total of up to 756 wells were overviewed to assess changes in water quality. The maximum capacity of the RBF systems of Budapest Waterworks is 1.0 million $\mathrm{m}^{3} /$ day; the recent average supply is about $456,000 \mathrm{~m}^{3} /$ day. Compared to the average discharge of the Danube River in Budapest, which stands at 200 million $\mathrm{m}^{3}$ /day, only $0.23 \%$ of the water is extracted from the river discharge via bank filtration. A unique situation occurs in Budapest whereby there is no riverbed clogging observed [10] and no distinct clogging layer exists in the riverbed affecting water quality. This may be due to the high river flow velocity of $0.8-1.6 \mathrm{~m} / \mathrm{s}$, the depth of the river and the related shear forces. At such levels of flow velocity, fine particles do not settle, only coarse sand and gravel do [11]. At many other RBF sites worldwide, clogging profoundly affects the infiltration rates of river water and results in a highly active biological layer in the riverbed which often notably contributes to water quality changes, especially considering oxygen consumption and attenuation of organic compounds [11-15].

Budapest Waterworks operates 756 RBF wells to supply water to 1.89 million inhabitants. The wells are predominantly located on Szentendre Island and Csepel Island (Figure 1). A detailed description of well types and operation procedures are to be found in Nagy-Kovács et al. [16].

\subsection{Groundwater Flow Modeling}

Travel times have been determined by ground water flow modeling using the MODFLOW software (USGS, Reston, VA, USA). The modeling served to determine the travel time of water particles arriving in the well. The ratio between river bank filtrate and ground water was investigated. The original proportion of the produced water is primarily controlled by the actual level of the Danube and the rate of drawdown. Calculations were carried out based on a 2-m average Danube level and a drawdown of $2 \mathrm{~m}$. Later, separate well capacities for different Danube water levels were also determined in 2012 [17]. Table 1 gives an overview of the distances and travel times between the Danube River and the production wells. 


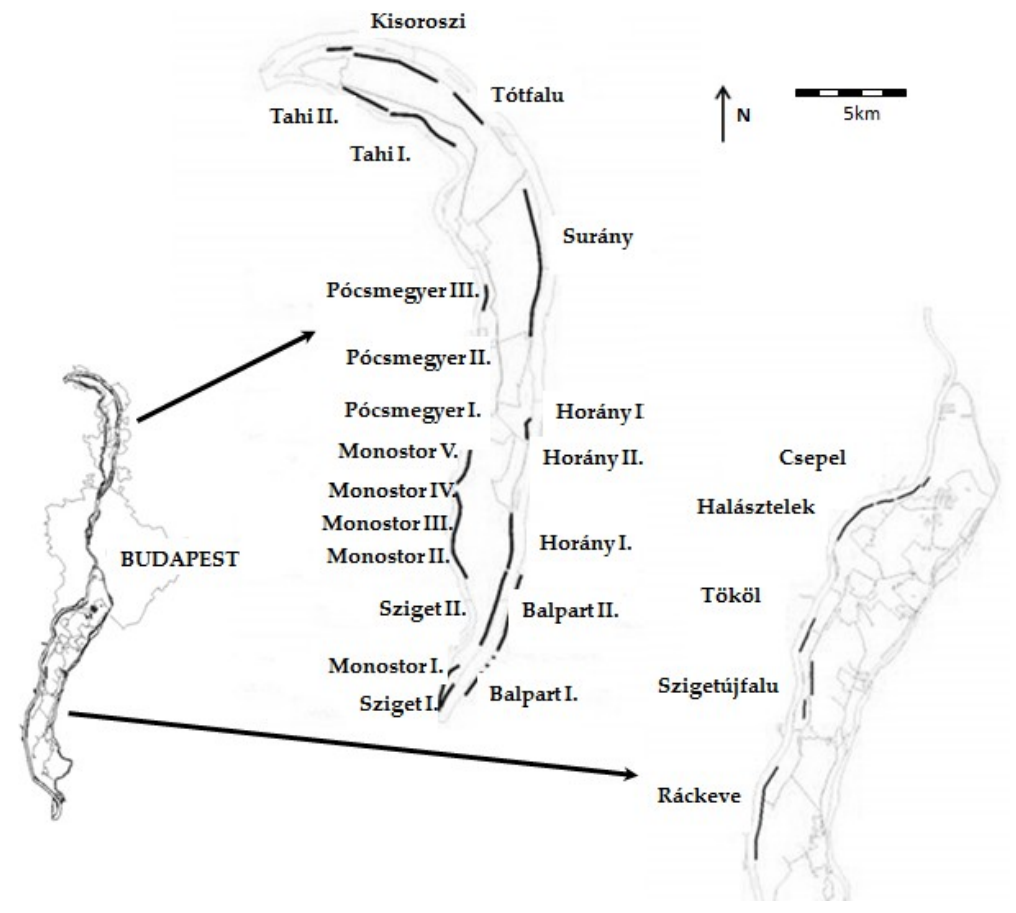

Figure 1. Location and names of well groups of the Budapest Waterworks at Szentendre Island (upstream the capital) and Csepel Island (downstream the capital).

Table 1. Distance and travel time between the Danube River and RBF wells in Budapest.

\begin{tabular}{ccccc}
\hline Well/Well Group & Type of Wells & $\begin{array}{c}\text { Distance between the } \\
\text { Riverbank and Wells } \\
(\mathbf{m})\end{array}$ & $\begin{array}{c}\text { Thickness of } \\
\text { Aquifer } \\
\text { (m) }\end{array}$ & $\begin{array}{c}\text { Travel Time of } \\
\text { Bank Filtrate } \\
\text { (days) }\end{array}$ \\
\hline Kisoroszi & HW & $40-370$ & $9-13$ & $13-17$ \\
Tótfalu & HW & 120 & $7-10$ & $14-22$ \\
Tahi I. & HW & 60 & $5-8$ & $3-6$ \\
Tahi II. & HW & $200-230$ & $5-8$ & $12-20$ \\
Surány well 1-7 & HW & $60-120$ & $7-12$ & $6-8$ \\
Surány well 8-14 & HW & $190-228$ & $7-12$ & $22-25$ \\
Surány well 15-20 & HW & $255-410$ & $7-12$ & $68-98$ \\
Horány I. & VW & 19 & $7-9$ & $4-6$ \\
Horány II. & VW & 19 & $7-9$ & $6-8$ \\
Horány III. & HW & $85-245$ & $7-9$ & $9-11$ \\
Pócsmegyer I. & VW, HW & $90-140$ & $5-12$ & $8-11$ \\
Pócsmegyer II. & HW & $0-60$ & $5-12$ & $2-4$ \\
Pócsmegyer III. & VW & 30 & $5-12$ & $2-4$ \\
Monostor I & HW & $30-270$ & $5-13$ & $11-12$ \\
Monostor II. & VW & 70 & $5-13$ & $9-12$ \\
Monostor III. & VW & 70 & $5-13$ & $7-9$ \\
Monostor IV. & VW & 40 & $5-13$ & $4-6$ \\
Monostor V. & VW, HW & $40-80$ & $5-13$ & $9-13$ \\
Sziget I. & HW & $10-35$ & $5-13$ & $2-5$ \\
Sziget II. & HW & $10-45$ & $5-13$ & $2-5$ \\
Balpart I. & HW, SW & $51-100$ & $5-10$ & $5-10$ \\
Balpart II. & HW & $62-203$ & $5-10$ & $2-5$ \\
Csepel & HW & $7-27$ & $9-17$ & $2-5$ \\
Halásztelek & HW & $24-113$ & $9-17$ & $2-25$ \\
Tököl & VW & $55-70$ & $5-13$ & $5-20$ \\
Szigetújfalu & HW & $374-860$ & $5-13$ & $100-220$ \\
Ráckeve & HW & $60-117$ & $8-15$ & $15-20$ \\
\hline & & &
\end{tabular}

HW—horizontal (collector) well, VW—drilled (vertical) well, SW—shaft well. 


\subsection{RBF Monitoring Network and Samples}

Water sampling from the river and the wells was carried out following the Hungarian guidelines and standards [18]. Analyses are carried out systematically and adjusted to changing circumstances to ensure safe and secure water supply and to gain data for optimal operation of the RBF systems. The Danube River was sampled at least weekly either on Szentendre Island or Csepel Island. Every well in operation was sampled regularly at least twice a year from its sampling tap. Some siphon systems were sampled at their collecting pipes.

All analytical methods for the determination of discussed parameters are provided in the Supplementary Material.

The minimum, median and maximum values were prepared. Due to the large number of data, short events such as floods or spills would not affect the median values which are used to determine removal rates for different groups of RBF wells.

For physical and chemical parameters, mean removal rates have been determined for the whole time period. Lowest and highest removal rates were calculated using the mean concentration in the river water and the maximum and the minimum concentration in the bank filtrate, respectively. As the sampled well water is a mixture of bank filtrate of different age depending on the location of infiltration in the riverbed, the depth of the flow path in the aquifer and the pumping rate of the well, pairing of data is not useful. In no case, data from the same date of sampling can be compared as the water sampled from the well is days to weeks old and has nothing to do with the river water quality at the sampling date. As RBF acts as a buffer for water quality, it is feasible to use the mean concentration in river water and to compare with minimum and maximum concentrations observed in the well water. For microbiological parameters, the mean logarithmic removal rate was calculated as the difference between the logarithm of the average cell count in Danube River water and the logarithm of the average cell count in the bank filtrate.

The available dataset has been discussed in five different Chapters (Sections 3.1-3.5). For all chapters, a table has been prepared to better demonstrate the results that have been analyzed during this study. Median values are in bold presented in the first row, the range of each parameter with minimum and maximum values is given in the second row, and $n$ represents the total number of samples for the parameter in italics. The dataset is formed by culminating results from the monitoring plan determined by Hungarian regulations, operation-related experiments, sampling during extreme hydrological events and a major accidental pollution event in the Danube River basin. Due to this fact, the number of samples $(n)$ varies for each parameter, as authors chose to present all reliable data from the period 2006-2017.

\section{Results and Discussion}

\subsection{Physical Parameters and Selected Cations and Anions}

This chapter summarizes the results of physical parameters, cations and anions measured on a regular basis. The temperature of the river water ranges from -1.4 to $26.3^{\circ} \mathrm{C}$ with a median of $13.2^{\circ} \mathrm{C}$ (Table 2). Due to the short distance between the riverbank and the wells and the heat capacity of the aquifer material, only a low buffering effect was observed - the temperature of bank filtrate ranges from 0.7 to $21.0^{\circ} \mathrm{C}$ with a median of $11.9^{\circ} \mathrm{C}$. As the aquifer thickness is only $5-17 \mathrm{~m}$ (Table 1 ), the buffering effect is lower in Budapest compared to other RBF sites with larger aquifer thickness, e.g., in Torgau with 50-60 m thickness [14,19]. The electrical conductivity (EC) of river water and bank filtrate varies from 283 to $652 \mu \mathrm{S} / \mathrm{cm}$ and from 303 to $1809 \mu \mathrm{S} / \mathrm{cm}$, respectively. The mean EC is very similar for the Danube River water and well groups on Szentendre Island, indicating a high portion of bank filtrate, which has been calculated from groundwater flow modeling as $60-80 \%$ [17]. The maximum EC values in bank filtrate, which are significantly higher than those of the river water are only observed on Csepel Island, where industrial and agricultural activities even outside of the well head protection zones are still affecting the water quality in some wells. The mean turbidity of bank filtrate is very low 
(0.05-0.07 NTU) compared to river water and the removal of particles is not a function of travel time. Slightly increased turbidity values on Csepel Island are related to iron and manganese precipitates.

Table 2. Physical parameters and selected cations and anions, median (min-max) values of Danube River water and bank filtrate with different travel time (t), Budapest, 2006-2017.

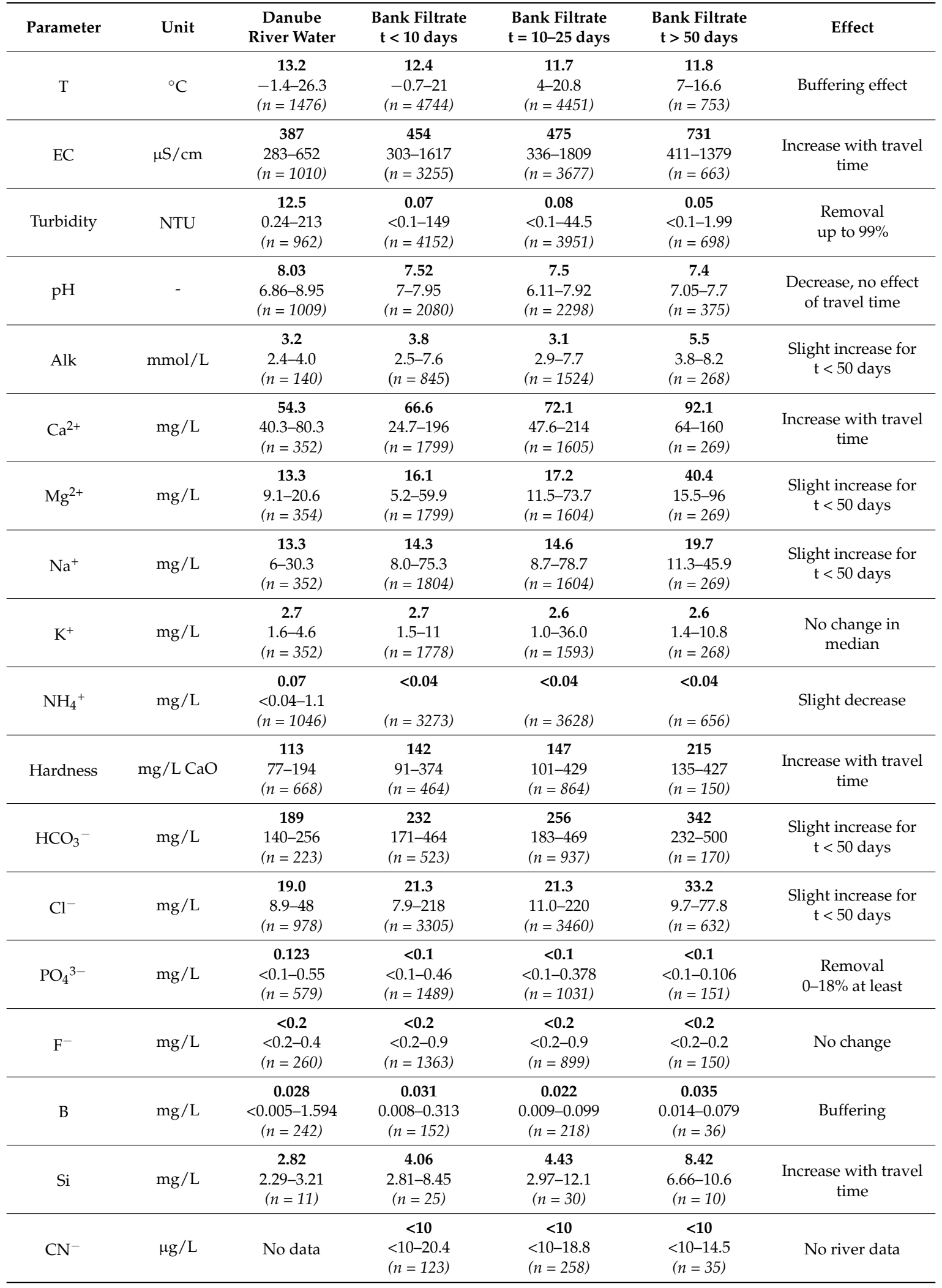


Despite the long-term operation of most of the wells, there is still a dissolution of carbonates in the aquifer, resulting in an increase in hardness ( $\mathrm{Ca}$ and $\mathrm{Mg}$ ) compared to river water. Sodium and potassium concentrations in river water and bank filtrate are within the same range.

As for sodium, chloride concentrations in river water and bank filtrate are within the same range, indicating a high portion of bank filtrate. Fluoride, boron, silicon and cyanide concentrations are at low levels both in river water and bank filtrate and do not pose any risk for the water supply. Phosphate levels in river water are below the LOD (limit of determination), but are surprisingly also found in the bank filtrate.

Seasonal temperature changes in river water and bank filtrate and flow-related changes in EC can be used to estimate travel times of the bank filtrate $[14,20]$. Figure 2 shows the temperature data for the Danube River water and well group Balpart II with a short travel time in the range of 2-5 days. It can be seen how the seasonal temperature variation of the river influences the river bank filtrate as the buffering effect of the aquifer is considered low. Also, a change in the water temperature variation can be seen starting from August of 2012 that is linked to the fact that the production rate decreased by $30 \%$ at the site.

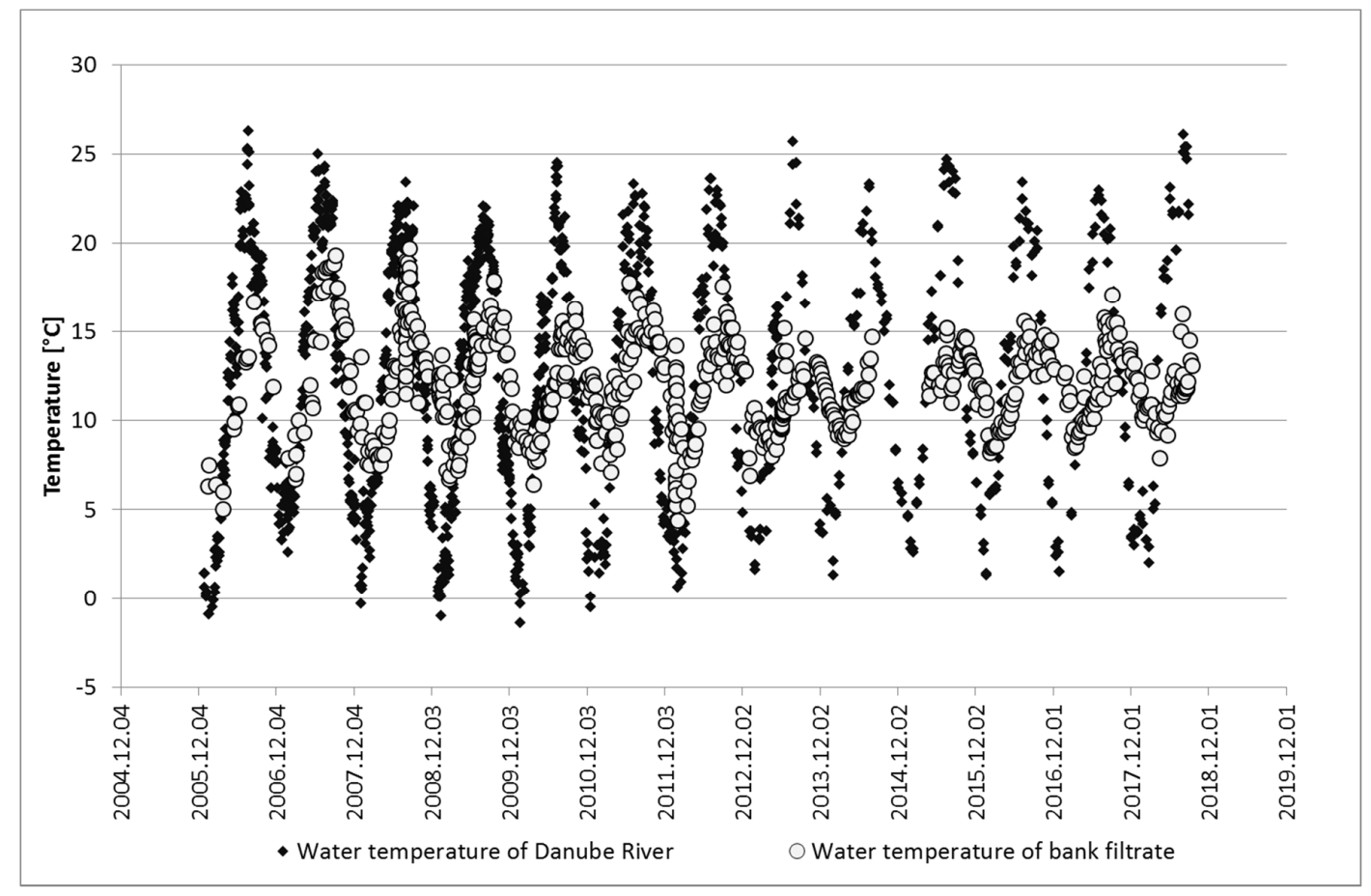

Figure 2. Seasonal temperature variation in Danube River water and bank filtrate, well group Balpart II, 2006-2018.

\subsection{Redox-Related Parameters}

The removal of organic compounds (mainly natural humic and fulvic acids) is of high relevance for the required post-treatment (to supply microbiologically stable drinking water) and especially for disinfection with regards to the potential formation of disinfection by-products. The total organic carbon (TOC) concentration in the Danube River water ranges from 1.6 to $10.0 \mathrm{mg} / \mathrm{L}$ (Table 3) and has a median similar to that of the Rhine River at Düsseldorf [21] and about half of the concentration in the Elbe River [14,19]. Despite the low input concentration, the removal rate for TOC is relatively high, ranging from 11 to $75 \%$. The TOC removal is higher if the travel time is longer. The removal of organic aromatic compounds causing UV absorption ranges between 0 and $92 \%$. The median specific UV-absorbance (calculated as $\mathrm{UV}_{254} / \mathrm{TOC}$ ) is $2.61 \mathrm{~L} /(\mathrm{m} \cdot \mathrm{mg}$ ) for Danube River water and 1.93-2.45 L/(m·mg) for bank filtrate. At the RBF site Torgau, Elbe River, Germany, the specific UV-absorbance of the river water was $2.94 \mathrm{~L} /(\mathrm{m} \cdot \mathrm{mg})$, increasing to $3.17 \mathrm{~L} /(\mathrm{m} \cdot \mathrm{mg})$ in the riverbed, 
where easily biodegradable and less UV-active organic compounds were removed, and decreased along the $>200 \mathrm{~m}$ long flow path to $2.54 \mathrm{~L} /(\mathrm{m} \cdot \mathrm{mg})$ due to further attenuation of UV-active compounds [14]. In Budapest, a similar removal indicates high removal of UV-active compounds.

Table 3. Redox related parameters, median (min-max) values, Danube River water and bank filtrate with different travel time (t), Budapest, 2006-2017.

\begin{tabular}{|c|c|c|c|c|c|c|}
\hline Parameter & Unit & $\begin{array}{c}\text { Danube } \\
\text { River Water }\end{array}$ & $\begin{array}{c}\text { Bank Filtrate } \\
t<10 \text { days }\end{array}$ & $\begin{array}{l}\text { Bank Filtrate } \\
t=10-25 \text { days }\end{array}$ & $\begin{array}{c}\text { Bank Filtrate } \\
t>50 \text { days }\end{array}$ & Effect \\
\hline TOC & $\mathrm{mg} / \mathrm{L}$ & $\begin{array}{c}2.8 \\
1.6-10.0 \\
(n=585)\end{array}$ & $\begin{array}{c}\mathbf{1 . 1} \\
0.7-2.5 \\
(n=319)\end{array}$ & $\begin{array}{c}\mathbf{1 . 1} \\
0.7-2.1 \\
(n=200)\end{array}$ & $\begin{array}{c}\mathbf{0 . 9} \\
0.7-1.3 \\
(n=10)\end{array}$ & $\begin{array}{c}\text { Removal } \\
11-75 \%\end{array}$ \\
\hline $\mathrm{UV}_{254}$ & $\mathrm{~m}^{-1}$ & $\begin{array}{c}7.4 \\
1-29.6 \\
(n=426)\end{array}$ & $\begin{array}{c}2.7 \\
0.7-7.5 \\
(n=2617)\end{array}$ & $\begin{array}{c}2.4 \\
0.6-12.7 \\
(n=2771)\end{array}$ & $\begin{array}{c}1.65 \\
0.55-6.9 \\
(n=500)\end{array}$ & $\begin{array}{c}\text { Removal } \\
0-92 \%\end{array}$ \\
\hline COD & $\mathrm{mg} / \mathrm{L}$ & $\begin{array}{c}2.8 \\
0.3-16.2 \\
(n=1039)\end{array}$ & $\begin{array}{c}\mathbf{0 . 7} \\
<0.2-2.6 \\
(n=3401)\end{array}$ & $\begin{array}{c}\mathbf{0 . 7} \\
<0.2-2.5 \\
(n=3639)\end{array}$ & $\begin{array}{c}\mathbf{0 . 4 4} \\
<0.2-2.4 \\
(n=657)\end{array}$ & $\begin{array}{c}\text { Removal } \\
7-93 \%\end{array}$ \\
\hline DO & $\mathrm{mg} / \mathrm{L}$ & $\begin{array}{c}\quad>7 \\
\text { near to } \\
\text { saturation }\end{array}$ & $\begin{array}{c}2.7 \\
0.2-11.1 \\
(n=173)\end{array}$ & $\begin{array}{c}\text { 3.1 } \\
0.2-11.1 \\
(n=97)\end{array}$ & $\begin{array}{c}2.3 \\
0.4-4.4 \\
(n=13)\end{array}$ & $\begin{array}{c}\text { No river } \\
\text { data set } \\
\text { available }\end{array}$ \\
\hline $\mathrm{NO}_{3}{ }^{-}$ & $\mathrm{mg} / \mathrm{L}$ & $\begin{array}{c}\mathbf{8 . 1} \\
2.9-17.8 \\
(n=1092)\end{array}$ & $\begin{array}{c}\mathbf{8 . 4} \\
<1-126 \\
(n=3531)\end{array}$ & $\begin{array}{c}\mathbf{7 . 1} \\
<1-144 \\
(n=3815)\end{array}$ & $\begin{array}{c}22.9 \\
2.2-89.6 \\
(n=661)\end{array}$ & $\begin{array}{l}\text { No effect at } \\
\text { short travel } \\
\text { times }\end{array}$ \\
\hline $\mathrm{NO}_{2}^{-}$ & $\mathrm{mg} / \mathrm{L}$ & $\begin{array}{c}\mathbf{0 . 0 5} \\
<0.03-0.91 \\
(n=1052)\end{array}$ & $\begin{array}{c}<0.03 \\
<0.03-0.82 \\
(n=3296)\end{array}$ & $\begin{array}{c}<0.03 \\
<0.03-0.53 \\
(n=3649)\end{array}$ & $\begin{array}{c}<0.03 \\
<0.03-0.19 \\
(n=656)\end{array}$ & $\begin{array}{c}\text { Decreasing } \\
\text { effect }\end{array}$ \\
\hline $\mathrm{Mn}$ & $\mu \mathrm{g} / \mathrm{L}$ & $\begin{array}{c}33.5 \\
1.9-415 \\
(n=757)\end{array}$ & $\begin{array}{c}\mathbf{1 . 3} \\
<1-1752 \\
(n=3358)\end{array}$ & $\begin{array}{c}\mathbf{1 . 9} \\
<1-3255 \\
(n=3722)\end{array}$ & $\begin{array}{c}3.9 \\
<1-135 \\
(n=657)\end{array}$ & $\begin{array}{c}\text { Removal } \\
0-97 \%\end{array}$ \\
\hline $\mathrm{Fe}$ & $\mu \mathrm{g} / \mathrm{L}$ & $\begin{array}{c}\mathbf{2 0 1} \\
<5-3600 \\
(n=1052)\end{array}$ & $\begin{array}{c}5.8 \\
<5-1670 \\
(n=918)\end{array}$ & $\begin{array}{c}7.2 \\
<5-3540 \\
(n=1215)\end{array}$ & $\begin{array}{c}\mathbf{6 . 5} \\
<5-82.2 \\
(n=257)\end{array}$ & $\begin{array}{c}\text { Removal } \\
0-98 \%\end{array}$ \\
\hline $\mathrm{SO}_{4}{ }^{2-}$ & $\mathrm{mg} / \mathrm{L}$ & $\begin{array}{c}31.8 \\
18.2-138.3 \\
(n=307)\end{array}$ & $\begin{array}{c}\mathbf{3 8 . 4} \\
20.7-438.8 \\
(n=2016)\end{array}$ & $\begin{array}{c}\mathbf{4 5 . 5} \\
20.7-491.9 \\
(n=1904)\end{array}$ & $\begin{array}{c}103 \\
18.4-351.6 \\
(n=319)\end{array}$ & $\begin{array}{c}\text { Slight } \\
\text { increase }\end{array}$ \\
\hline
\end{tabular}

The chemical oxygen demand (COD) removal rates during RBF were about 7-93\% but cannot be used as the TOC to assess the removal of organic compounds as it cumulatively removes all oxidizable compounds present in the water, including inorganic constituents such as ammonium and iron.

Both the dissolved oxygen concentration in the river water and the consumption in the aquifer by biological processes are strongly temperature dependent. The median dissolved oxygen (DO) concentration decreased from $8 \mathrm{mg} / \mathrm{L}$ in river water to $2.3-3.1 \mathrm{mg} / \mathrm{L}$ in bank filtrate. Considering the minimum values, it becomes obvious that RBF at Budapest is predominantly operated under oxic conditions; however, anoxic conditions occur during summer months. On Szentendre Island, no increase in Mn and Fe concentration was observed, whereas on Csepel Island, there was an increase in $\mathrm{Mn}$ and $\mathrm{Fe}$ to $15 \mu \mathrm{g} / \mathrm{L}$ and $43 \mu \mathrm{g} / \mathrm{L}$, respectively, requiring post-treatment. The aquifer material on Csepel Island is of smaller grain size. Here, the river water quality is affected by effluents from the city, probably resulting in a higher portion of biodegradable organic carbon. Sulphate concentrations in river water and bank filtrate are very similar, indicating no sulphate reduction during RBF.

Although the temperature dependency of biological nitrate removal (denitrification) during RBF has been reported for many sites [22,23], a strong effect on dissolved organic carbon (DOC) removal has been rarely observed as DOC transport is a complex process and is also affected by temperature-related adsorption and desorption interactions $[19,23]$. The Danube and the bank filtrate at Budapest have very similar DOC and TOC concentrations. Also, it has been observed that these concentrations have 
decreased due to the improving raw water quality and decreased production rate. In general, the median TOC concentration in bank filtrate was $1.0 \mathrm{mg} / \mathrm{L}$ in summer and $1.6 \mathrm{mg} / \mathrm{L}$ in winter (data 2006-2017, $n=529$ ). It has to be mentioned that TOC still includes organic particles and is only at the same level as DOC for the bank filtrate, not for river water. Elevated nitrate concentrations under longer travel times $(t>50)$ are related to the higher groundwater portion.

\subsection{Metals}

Metal concentrations are listed in alphabetical order of the chemical symbol of the element. Metal concentrations were below the limit determined by the Hungarian regulations [24,25] at the RBF sites in Budapest, for the river water and the bank filtrate (Table 4). All concentrations are below the limits of the drinking water quality guideline [24]. The removal of heavy metals follows the sequence: $\mathrm{Cr}>$ $\mathrm{Zn}>\mathrm{Cu}>\mathrm{Pb}>\mathrm{Ni}>\mathrm{Cd}>\mathrm{Co}>\mathrm{Al}$. The range of removal is in agreement with a general removal of 20-70\% for $\mathrm{Cd}, \mathrm{Co}, \mathrm{Cu}, \mathrm{Ni}, \mathrm{Zn}$ under oxic conditions according to [26].

Table 4. Median (min-max) metal concentrations in Danube river water and bank filtrate (BF) with different travel time (t), 2006-2017.

\begin{tabular}{|c|c|c|c|c|c|c|}
\hline Parameter & Unit & $\begin{array}{c}\text { Danube } \\
\text { River Water }\end{array}$ & $\begin{array}{c}\text { Bank Filtrate } \\
t<10 \text { days }\end{array}$ & $\begin{array}{c}\text { Bank Filtrate } \\
t=10-25 \text { days }\end{array}$ & $\begin{array}{c}\text { Bank Filtrate } \\
t>50 \text { days }\end{array}$ & Effect \\
\hline $\mathrm{Al}$ & $\mu \mathrm{g} / \mathrm{L}$ & $\begin{array}{c}157 \\
5.2-4261 \\
(n=163)\end{array}$ & $\begin{array}{c}<5 \\
<5-107 \\
(n=192)\end{array}$ & $\begin{array}{c}<5 \\
<5-1114 \\
(n=267)\end{array}$ & $\begin{array}{c}<5 \\
<5-289 \\
(n=43)\end{array}$ & $\begin{array}{c}\text { Nearly complete } \\
\text { removal }\end{array}$ \\
\hline $\mathrm{Sb}$ & $\mu \mathrm{g} / \mathrm{L}$ & $\begin{array}{c}<0.5 \\
<0.5-1.28 \\
(n=159)\end{array}$ & $\begin{array}{c}<0.5 \\
<0.5-2.5 \\
(n=158)\end{array}$ & $\begin{array}{c}<0.5 \\
<0.5-2.8 \\
(n=229)\end{array}$ & $\begin{array}{c}<0.5 \\
<0.5-0.9 \\
(n=38)\end{array}$ & Results below LOD \\
\hline As & $\mu \mathrm{g} / \mathrm{L}$ & $\begin{array}{c}\mathbf{1 . 8} \\
1.0-7.7 \\
(n=163)\end{array}$ & $\begin{array}{c}1.7 \\
<1-3.7 \\
(n=325)\end{array}$ & $\begin{array}{c}\mathbf{1 . 5} \\
<1-6 \\
(n=521)\end{array}$ & $\begin{array}{c}<1 \\
<1-6.9 \\
(n=88)\end{array}$ & $\begin{array}{l}\text { Little change, } \\
\text { around LOD }\end{array}$ \\
\hline $\mathrm{Ba}$ & $\mu \mathrm{g} / \mathrm{L}$ & $\begin{array}{c}35.1 \\
<5-185 \\
(n=266)\end{array}$ & $\begin{array}{c}40.2 \\
<5-126 \\
(n=172)\end{array}$ & $\begin{array}{c}42.9 \\
19-126 \\
(n=257)\end{array}$ & $\begin{array}{c}47.7 \\
24.3-102 \\
(n=43)\end{array}$ & Slight increase \\
\hline $\mathrm{Cd}$ & $\mu \mathrm{g} / \mathrm{L}$ & $\begin{array}{c}0.2 \\
<0.2-0.8 \\
(n=266)\end{array}$ & $\begin{array}{c}<0.2 \\
<0.2-0.677 \\
(n=192)\end{array}$ & $\begin{array}{c}\mathbf{0 . 2} \\
<0.2-0.5 \\
(n=266)\end{array}$ & $\begin{array}{c}<0.2 \\
(n=43)\end{array}$ & $\begin{array}{l}\text { Slight decrease, } \\
\text { results close to LOD }\end{array}$ \\
\hline $\mathrm{Cr}$ & $\mu \mathrm{g} / \mathrm{L}$ & $\begin{array}{c}1.2 \\
<1-23.3 \\
(n=266)\end{array}$ & $\begin{array}{c}1.0 \\
<1-6.6 \\
(n=192)\end{array}$ & $\begin{array}{c}\mathbf{1 . 0} \\
<1-21.9 \\
(n=267)\end{array}$ & $\begin{array}{c}1.2 \\
<1-3.1 \\
(n=45)\end{array}$ & $\begin{array}{c}\text { Removal } \\
0-16 \% \text {, results close } \\
\text { to LOD }\end{array}$ \\
\hline Co & $\mu \mathrm{g} / \mathrm{L}$ & $\begin{array}{c}0.25 \\
<0.2-2.4 \\
(n=266)\end{array}$ & $\begin{array}{c}<0.2 \\
<0.2-2.0 \\
(n=172)\end{array}$ & $\begin{array}{c}<0.2 \\
<0.2-0.4 \\
(n=257)\end{array}$ & $\begin{array}{c}<0.2 \\
<0.2-1.4 \\
(n=43)\end{array}$ & $\begin{array}{c}\text { Removal } \\
0-20 \% \\
\text { (at least) }\end{array}$ \\
\hline $\mathrm{Hg}$ & $\mu \mathrm{g} / \mathrm{L}$ & $\begin{array}{c}<0.05 \\
<0.05-0.65 \\
(n=116)\end{array}$ & $\begin{array}{c}<0.05 \\
<0.05-1.2 \\
(n=175)\end{array}$ & $\begin{array}{c}<0.05 \\
<0.05-0.8 \\
(n=263)\end{array}$ & $\begin{array}{c}<0.05 \\
(n=43)\end{array}$ & Results below LOD \\
\hline Mo & $\mu \mathrm{g} / \mathrm{L}$ & $\begin{array}{c}\mathbf{1 . 0} \\
<1-23 \\
(n=265)\end{array}$ & $\begin{array}{c}<1 \\
<1-7.6 \\
(n=172)\end{array}$ & $\begin{array}{c}<1 \\
<1-20.4 \\
(n=258)\end{array}$ & $\begin{array}{c}<1 \\
<1-2.1 \\
(n=45)\end{array}$ & $\begin{array}{l}\text { Results for BF below } \\
\text { LOD }\end{array}$ \\
\hline
\end{tabular}


Table 4. Cont

\begin{tabular}{|c|c|c|c|c|c|c|}
\hline Parameter & Unit & $\begin{array}{c}\text { Danube } \\
\text { River Water }\end{array}$ & $\begin{array}{c}\text { Bank Filtrate } \\
t<10 \text { days }\end{array}$ & $\begin{array}{c}\text { Bank Filtrate } \\
t=10-25 \text { days }\end{array}$ & $\begin{array}{c}\text { Bank Filtrate } \\
t>50 \text { days }\end{array}$ & Effect \\
\hline $\mathrm{Ni}$ & $\mu \mathrm{g} / \mathrm{L}$ & $\begin{array}{c}1.672 \\
<1-105 \\
(n=267)\end{array}$ & $\begin{array}{c}<1 \\
<1-28.6 \\
(n=192)\end{array}$ & $\begin{array}{c}<1 \\
<1-89.9 \\
(n=267)\end{array}$ & $\begin{array}{c}<1 \\
<1-4.46 \\
(n=45)\end{array}$ & $\begin{array}{l}\text { Results for BF below } \\
\text { LOD }\end{array}$ \\
\hline Se & $\mu \mathrm{g} / \mathrm{L}$ & $\begin{array}{c}<1 \\
<1-1.0 \\
(n=163)\end{array}$ & $\begin{array}{c}<1 \\
<1-3.6 \\
(n=191)\end{array}$ & $\begin{array}{c}<1 \\
<1-3.6 \\
(n=265)\end{array}$ & $\begin{array}{c}1.6 \\
<1-4.2 \\
(n=43)\end{array}$ & Little change \\
\hline $\mathrm{Ag}$ & $\mu \mathrm{g} / \mathrm{L}$ & $\begin{array}{c}<1 \\
<1-4 \\
(n=266)\end{array}$ & $\begin{array}{c}<1 \\
<1-2.3 \\
(n=178)\end{array}$ & $\begin{array}{c}<1 \\
<1-4.4 \\
(n=258)\end{array}$ & $\begin{array}{c}<1 \\
<1-0.839 \\
(n=43)\end{array}$ & Results below LOD \\
\hline $\mathrm{Sr}$ & $\mathrm{mg} / \mathrm{L}$ & $\begin{array}{c}\mathbf{0 . 4} \\
0.24-0.32 \\
(n=3)\end{array}$ & $\begin{array}{c}\mathbf{0 . 3 3} \\
0.23-0.95 \\
(n=20)\end{array}$ & $\begin{array}{c}\mathbf{0 . 3} \\
0.26-0.46 \\
(n=23)\end{array}$ & $\begin{array}{c}\mathbf{0 . 5 8} \\
0.46-0.78 \\
(n=8)\end{array}$ & $\begin{array}{l}\text { River data not } \\
\text { sufficient }\end{array}$ \\
\hline $\mathrm{Zn}$ & $\mu \mathrm{g} / \mathrm{L}$ & $\begin{array}{c}12.1 \\
<5-222 \\
(n=267)\end{array}$ & $\begin{array}{c}\mathbf{5 . 8} \\
<5-119.5 \\
(n=172)\end{array}$ & $\begin{array}{c}6.2 \\
<5-175 \\
(n=257)\end{array}$ & $\begin{array}{c}\mathbf{1 1 . 5} \\
<5-166 \\
(n=43)\end{array}$ & Removal 0-59\% \\
\hline
\end{tabular}

In October 2010, at Kolontár beside Torna Creek, located 120 km upstream from the Danube River, the dam of a reservoir containing red mud deposits from a bauxite processing company broke, and a so-called "red mud spill" happened. The mud directly affected Torna Creek, a tertiary tributary of the Danube River, ultimately discharging into the Danube River. In Budapest, no change in color was observed in the Danube; however, a slight increase in $\mathrm{pH}$ and increased concentrations of aluminium and molybdenum were determined. Figures 3 and 4 show the aluminium and molybdenum concentrations in Danube River water and adjacent RBF wells as a consequence of the spill. An increase in aluminium concentration in the river lasting about four days was observed. No water quality changes were detected in the RBF wells during a continuous monitoring of two years following the accidental pollution. This result clearly indicates the robustness and buffering capacity of RBF against industrial spills.

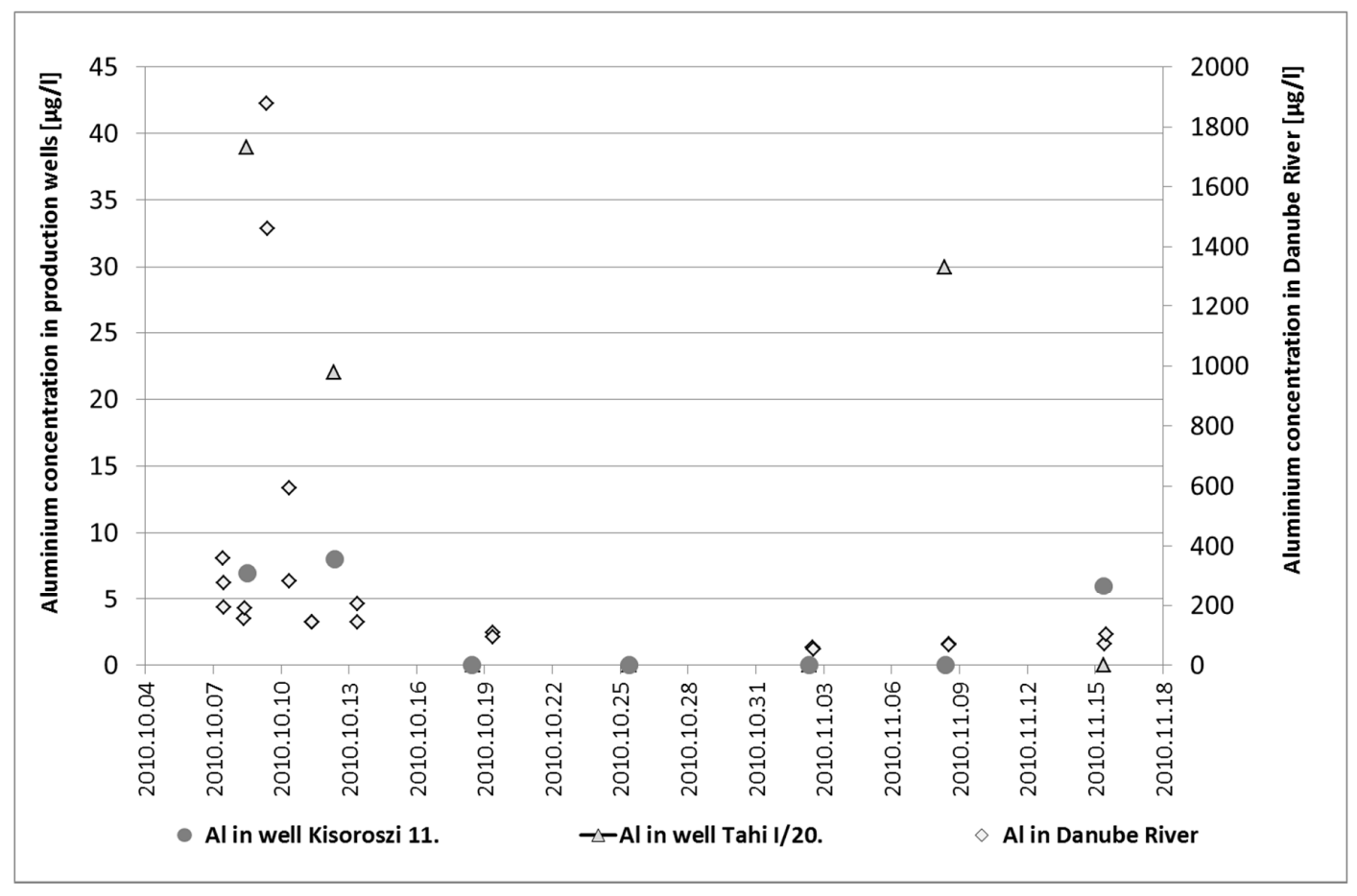

Figure 3. Aluminium concentrations in Danube River water and bank filtrate in production wells during the red mud spill in October 2010. Lower LOD is $5 \mu \mathrm{g} / \mathrm{L}$ for aluminium. 


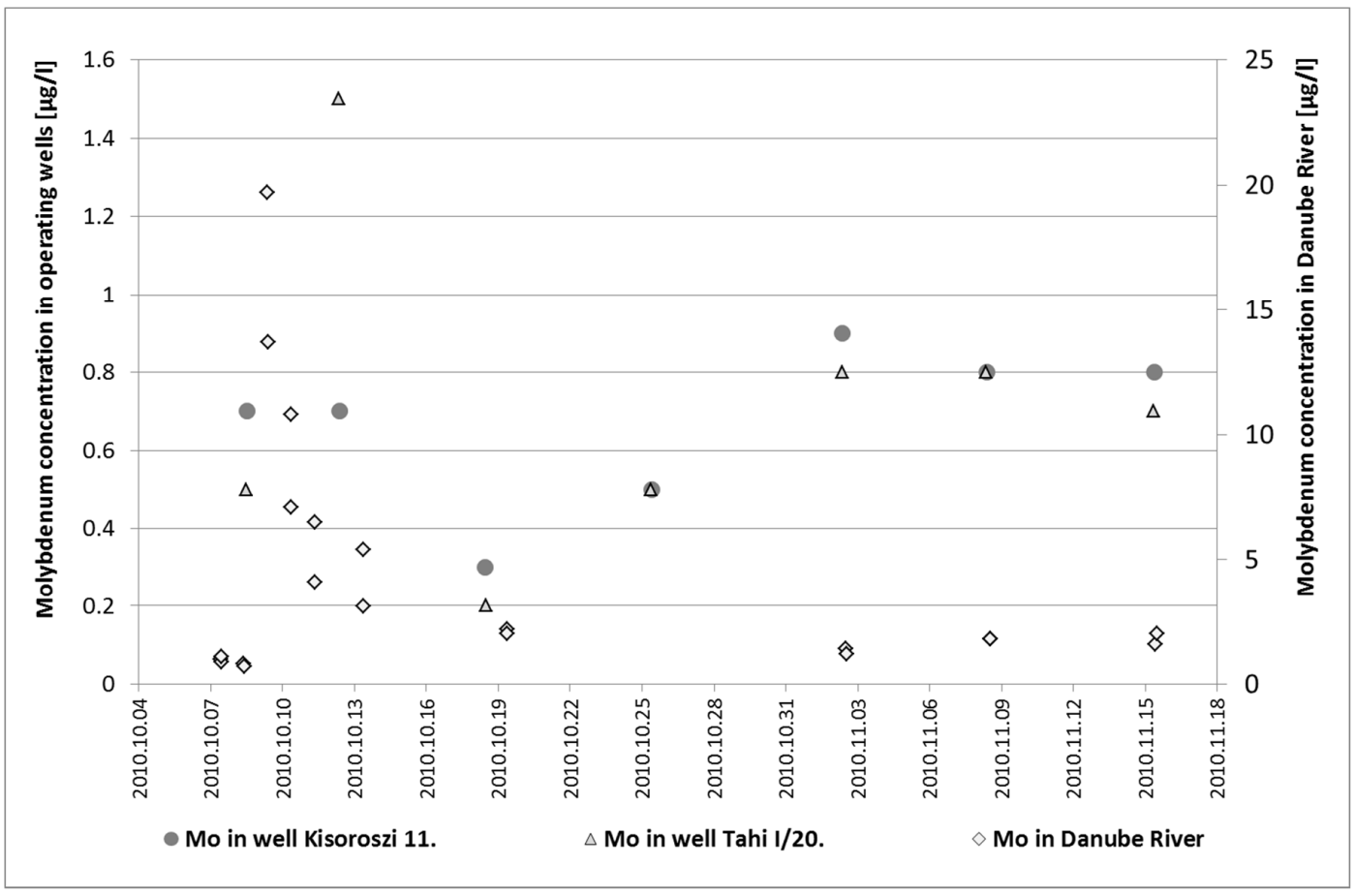

Figure 4. Molybdenum concentrations in Danube River water and bank filtrate in production wells during the red mud spill in October 2010. Lower LOD is $1 \mu \mathrm{g} / \mathrm{L}$ for molybdenum.

\subsection{Microbiological Parameters}

The microbiological pollution of the Danube River is more prominent in the downstream regions of large European rivers [2]. High bacterial counts in river water are typically observed during floods if direct wastewater effluents discharge into the river [27]. Sporadic microbiological non-compliances in the RBF wells occur very rarely and only as an effect of floods, independent from the bacteria numbers in the river water. In the case of any observed bacterial breakthrough into a well, the well operation is modified as described in Nagy-Kovács et al. [15]. Out of 9153 samples from RBF wells, only 13 samples showed a positive result for total coliforms. Escherichia coli (E. coli) was never detected in any of the wells. The heterotrophic plate counts (HPC) at $22{ }^{\circ} \mathrm{C}$ for bank filtrate were found to range from 0 to 300 counts per $\mathrm{mL}$ in $96 \%$ of all samples. Based on the experience of the water quality control laboratory operated by the Budapest Waterworks, all values below $400 \mathrm{c} / \mathrm{mL}$ are categorized not critical. The Hungarian drinking water guideline [24] does not define a limit for this as it may vary from site to site but requires certain measures if any sudden change in the number occurs.

The mean log removal rates for total coliforms, enterococci and Pseudomonas aeruginosa are 2.8, 1.9 and 1.8 respectively (Table 5). Escherichia coli and Clostridium perfringens are not included in Table 6 as there are no Danube River measurements for these parameters. Despite the short travel times at Budapest, these removal rates are only slightly lower than ranges found at other RBF sites [27-29]. We must highlight that even during higher bacterial loads of the river water, the bank filtrate was of high quality. If the highest total coliform count (TCC) value in river water is taken as input, a log removal of 3.5 (99.95\%) would be calculated. Thus, the high efficiency of RBF to remove particles (turbidity) and potential pathogens is proven also for the Budapest RBF systems. 
Table 5. Microbiological parameters, median (min-max), Danube River water and bank filtrate with different travel time (t), 2006-2017.

\begin{tabular}{|c|c|c|c|c|c|c|}
\hline Parameter & Unit & $\begin{array}{c}\text { Danube } \\
\text { River }\end{array}$ & $\begin{array}{c}\text { Bank Filtrate } \\
t<10 \text { days }\end{array}$ & $\begin{array}{c}\text { Bank Filtrate } \\
t=10-25 \text { days }\end{array}$ & $\begin{array}{c}\text { Bank Filtrate } \\
t>50 \text { days }\end{array}$ & $\begin{array}{c}\text { Log } \\
\text { Removal }\end{array}$ \\
\hline HPC 22 & $\mathrm{c} / \mathrm{mL}$ & $\begin{array}{c}480 \\
0-30,000 \\
(n=894)\end{array}$ & $\begin{array}{c}\mathbf{0} \\
0-30,000 \\
(n=4381)\end{array}$ & $\begin{array}{c}\mathbf{0} \\
0-60,000 \\
(n=4068)\end{array}$ & $\begin{array}{c}\mathbf{0} \\
0-26,000 \\
(n=706)\end{array}$ & 2.7 \\
\hline HPC 37 & $\mathrm{c} / \mathrm{mL}$ & $\begin{array}{c}220 \\
0-18,000 \\
(n=728)\end{array}$ & $\begin{array}{c}\mathbf{0} \\
0-40,000 \\
(n=3275)\end{array}$ & $\begin{array}{c}\mathbf{0} \\
0-50,000 \\
(n=1709)\end{array}$ & $\begin{array}{c}\mathbf{0} \\
0-16,000 \\
(n=215)\end{array}$ & 2.3 \\
\hline TCC & $\mathrm{c} / 100 \mathrm{~mL}$ & $\begin{array}{c}660 \\
0-1600 \\
(n=890)\end{array}$ & $\begin{array}{c}\mathbf{0} \\
0-102 \\
(n=4371)\end{array}$ & $\begin{array}{c}\mathbf{0} \\
0-500 \\
(n=4071)\end{array}$ & $\begin{array}{c}\mathbf{0} \\
0-7 \\
(n=711)\end{array}$ & 2.8 \\
\hline Enterococci & $\mathrm{c} / 100 \mathrm{~mL}$ & $\begin{array}{c}75 \\
12-360 \\
(n=245)\end{array}$ & $\begin{array}{c}\mathbf{0} \\
0-160 \\
(n=2851)\end{array}$ & $\begin{array}{c}\mathbf{0} \\
0-3 \\
(n=987)\end{array}$ & $\begin{array}{c}\mathbf{0} \\
0-0 \\
(n=142)\end{array}$ & 1.9 \\
\hline $\begin{array}{c}\text { Pseudomonas } \\
\text { aeruginosa }\end{array}$ & $\mathrm{c} / 100 \mathrm{~mL}$ & $\begin{array}{c}\mathbf{7 0} \\
2-2800 \\
(n=440)\end{array}$ & $\begin{array}{c}\mathbf{0} \\
0-160 \\
(n=2846)\end{array}$ & $\begin{array}{c}\mathbf{0} \\
0-80 \\
(n=996)\end{array}$ & $\begin{array}{c}\mathbf{0} \\
0-2 \\
(n=141)\end{array}$ & 1.8 \\
\hline
\end{tabular}

\subsection{Biological Parameters}

The measurement of biological parameters is required by the Hungarian legislation [24]. The dataset is unique, as there are only few similar studies at RBF sites known from other countries. For the majority of the samples, no positive results were obtained-see median values in Table 6 . As for the parameters of protozoa, other protozoa, other worms and iron- and manganese bacteria results are not listed in Table 6 as no river water results are monitored in accordance with Hungarian regulations. For example, out of 1074 samples for protozoa in bank filtrate, only 31 samples were positive.

Table 6. Biological parameters, median (min-max), Danube River water and bank filtrate with different travel time (t), 2006-2017.

\begin{tabular}{|c|c|c|c|c|c|c|}
\hline Parameter & Unit & $\begin{array}{c}\text { Danube River } \\
\text { Water }\end{array}$ & $\begin{array}{c}\text { Bank Filtrate } \\
t<10 \text { days }\end{array}$ & $\begin{array}{c}\text { Bank Filtrate } \\
t=10-25 \text { days }\end{array}$ & $\begin{array}{c}\text { Bank Filtrate } \\
t>50 \text { days }\end{array}$ & Removal \\
\hline Algae & $\mathrm{c} / \mathrm{L}$ & $\begin{array}{c}24 \\
1,727,200-66,739,440 \\
(n=797)\end{array}$ & $\begin{array}{c}\mathbf{0} \\
0-1,464,542 \\
(n=2544)\end{array}$ & $\begin{array}{c}\mathbf{0} \\
0-10,494 \\
(n=2204)\end{array}$ & $\begin{array}{c}\mathbf{0} \\
0-26 \\
(n=356)\end{array}$ & $100 \%$ \\
\hline Protozoa & $c / L$ & No measurement & $\begin{array}{c}\mathbf{0} \\
0-360 \\
(n=446)\end{array}$ & $\begin{array}{c}\mathbf{0} \\
0-1503 \\
(n=543)\end{array}$ & $\begin{array}{c}\mathbf{0} \\
0-1 \\
(n=85)\end{array}$ & $\begin{array}{c}\text { No river } \\
\text { data }\end{array}$ \\
\hline $\begin{array}{c}\text { Other } \\
\text { protozoa }\end{array}$ & $c / L$ & No measurement & $\begin{array}{c}\mathbf{0} \\
0-50 \\
(n=1059)\end{array}$ & $\begin{array}{c}\mathbf{0} \\
0-8 \\
(n=963)\end{array}$ & $\begin{array}{c}\mathbf{0} \\
0-288 \\
(n=194)\end{array}$ & $\begin{array}{c}\text { No river } \\
\text { data }\end{array}$ \\
\hline Nematodes & $\mathrm{c} / \mathrm{L}$ & $\begin{array}{c}\mathbf{0} \\
0-0 \\
(n=21)\end{array}$ & $\begin{array}{c}\mathbf{0} \\
0-8 \\
(n=1358)\end{array}$ & $\begin{array}{c}\mathbf{0} \\
0-12 \\
(n=1381)\end{array}$ & $\begin{array}{c}\mathbf{0} \\
0-3 \\
(n=256)\end{array}$ & - \\
\hline Amoebae & $\mathrm{c} / \mathrm{L}$ & $\begin{array}{c}0 \\
0-1 \\
(n=23)\end{array}$ & $\begin{array}{c}\mathbf{0} \\
0-42 \\
(n=1358)\end{array}$ & $\begin{array}{c}\mathbf{0} \\
0-8 \\
(n=1381)\end{array}$ & $\begin{array}{c}\mathbf{0} \\
0-2 \\
(n=256)\end{array}$ & - \\
\hline Fungi & $\mathrm{c} / \mathrm{L}$ & $\begin{array}{c}\mathbf{0} \\
0-0 \\
(n=23)\end{array}$ & $\begin{array}{c}\mathbf{0} \\
0-18 \\
(n=1358)\end{array}$ & $\begin{array}{c}\mathbf{0} \\
0-2 \\
(n=1381)\end{array}$ & $\begin{array}{c}\mathbf{0} \\
0-0 \\
(n=256)\end{array}$ & - \\
\hline $\mathrm{Fe} / \mathrm{Mn}$ bact. & $\mathrm{c} / \mathrm{L}$ & No measurement & $\begin{array}{c}97 \\
0-238,440 \\
(n=1358)\end{array}$ & $\begin{array}{c}97 \\
0-8,253,349 \\
(n=1381)\end{array}$ & $\begin{array}{c}24 \\
0-7610 \\
(n=256)\end{array}$ & $\begin{array}{c}\text { No river } \\
\text { data }\end{array}$ \\
\hline
\end{tabular}


An observed increase in algae numbers in bank filtrate during floods indicates surface water entering into the properly sealed wells via preferential flow paths in the subsurface (Figure 5). All well heads and pump houses are located above the highest observed flood levels or protected against surface water entrance. Additionally, a well reconstruction program to rehabilitate the well structure and sealing to prevent by-passes of surface water is nearly complete. Algae are used as a primary indicator to check if a well is affected (under risk) by direct surface water input. This is preferred against the use of bacteriological methods as they require more time for analysis.

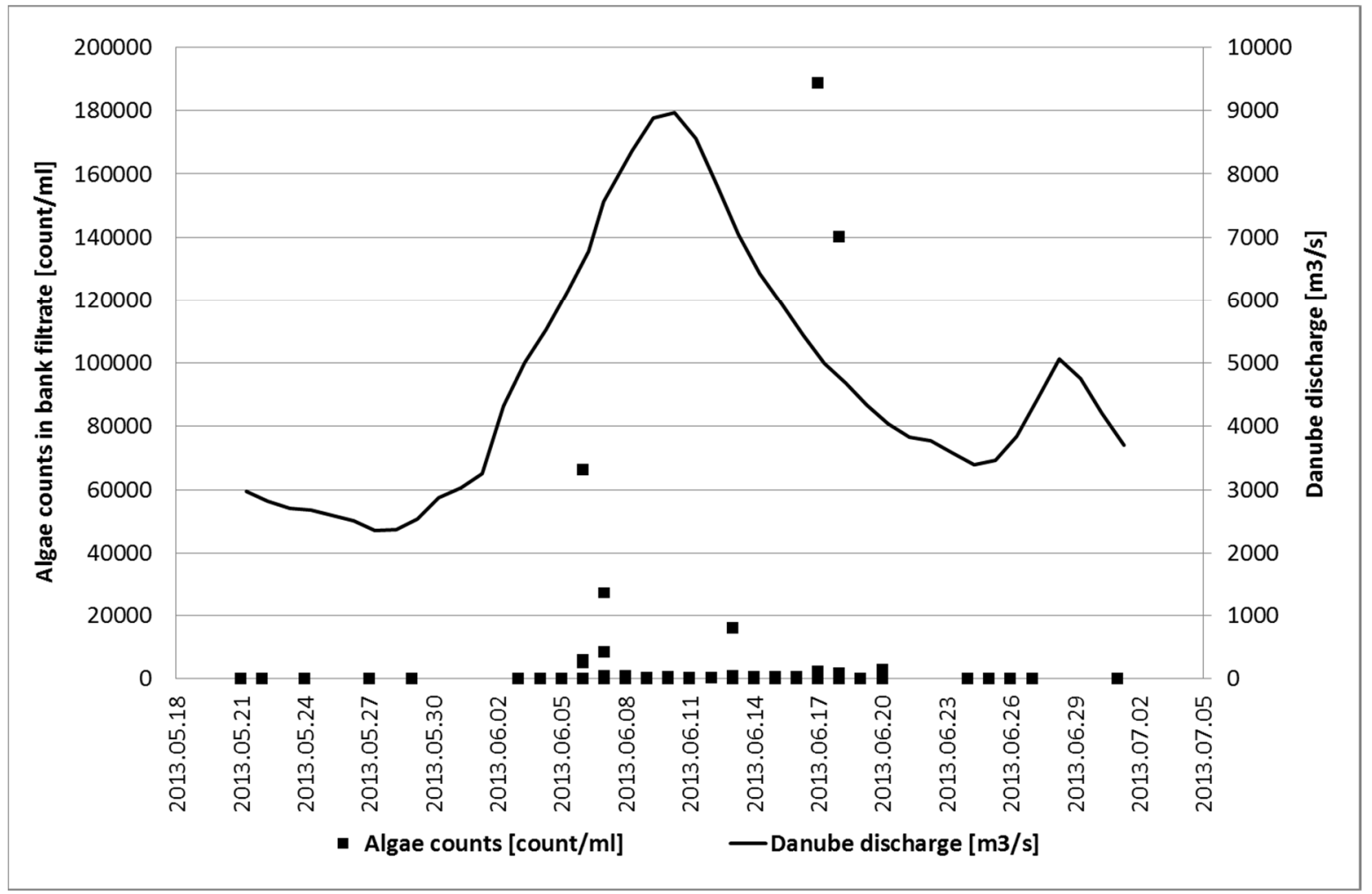

Figure 5. Algae counts in bank filtrate and Danube discharge values during a flood event in 2013.

\section{Conclusions}

The present study gives an overview of the Danube River water quality and the bank filtrate of related well groups in Budapest. Three different categories were determined for bank filtrates of the operating well groups based on travel times. The large amount of data enabled us to draw robust conclusions on the effect of RBF for the majority of analyzed parameters. Additionally, the effect of different environmental factors on the RBF systems was considered through multiple examples. Results in this case reassured the premise that this natural water treatment process is effective, even under extreme weather conditions.

The analyzed results serve as output of a monitoring procedure principally serving to support water safety and security objectives. Therefore, it should be regarded as an adaptive system that requires continuous updating. A well-defined monitoring program could serve to further investigate the particular characteristics and behavior of RBF systems in future. Considering that the majority of water resources centered around RBF originate in Hungary, the results of such research would serve to increase water safety at a national level.

Supplementary Materials: The following are available online at http:/ / www.mdpi.com/2073-4441/11/2/302/s1, Table S1: Parameters and analytical methods. 
Author Contributions: Z.N.-K. and T.G. prepared the article draft. J.D. prepared hydrogeological data. K.C.-M. was responsible for water quality data collection. E.F. helped in the literature review. G.T. participated in project coordination. All co-authors reviewed and edited the article draft.

Funding: All primary data were collected within the AquaNES project. This project has received funding from the European Union's Horizon 2020 Research and Innovation Program under grant no. 689450.

Acknowledgments: This study was based on the excellent work performed by many staff members of the Budapest Waterworks, from water sampling, analysis up to data management.

Conflicts of Interest: The authors declare no conflict of interest. The funding sponsors had no role in the design of the study; in the collection, analyses, or interpretation of data; in the writing of the manuscript, and in the decision to publish the results.

\section{References}

1. Ray, C.; Melin, G.; Linsky, R.B. (Eds.) Riverbank Filtration: Improving Source Water Quality; Kluwer Academic Publishers: Dordrecht, The Netherlands, 2002.

2. Barreto, S.; Bártfai, B.; Engloner, A.; Liptay, Á.Z.; Madarász, T.; Vargha, M. Water in Hungary, Status overview for the National Water Programme of the Hungarian Academy of Science. (Document of the National Water Programme). Budapest, Hungary, 2017. Available online: https://mta.hu (accessed on 11 February 2019).

3. Davidesz, J.; Debreczeny, L. Long-Term Sustainability of RBF Systems from Aspects of Availability and Capacity. In Proceedings of the MAVÍZ Conference, Sopron, Hungary, 11-12 June 2009. (In Hungarian)

4. László, F. The Hungarian experience with riverbank filtration. In Riverbank Filtration: The Future Is NOW! Proceedings of the 2nd International Riverbank Filtration Conference, Cincinnati, OH, USA, 16-19 September 2003; Melin, G., Ed.; National Water Research Institute: Fountain Valley, CA, USA, 2003.

5. Massmann, G.; Nogetzig, A.; Taute, T.; Pekdeger, A. Seasonal and spatial distribution of redox zone during lake bank filtration in Berlin, Germany. Environ. Geol. 2008, 54, 53-65. [CrossRef]

6. Sprenger, C.; Lorenzen, G.; Hülshoff, I.; Grützmacher, G.; Ronghang, M.; Pekdeger, A. Vulnerability of bank filtration systems to climate change. Sci. Total Environ. 2011, 409, 655-663. [CrossRef] [PubMed]

7. Bertelkamp, C.; Verliefde, A.R.D.; Schoutteten, K.; VanHaecke, L.; Vand Bussche, J.; Singhal, N.; van der Hoek, J.P. The effect of redox conditions and adaptation time on organic micropollutant removal during river bank filtration: A laboratory scale column study. Sci. Total Environ. 2016, 544, 309-318. [CrossRef] [PubMed]

8. Kischner, A.-K.-T.; Reischer, G.H.; Kakwerth, S.; Savio, D.; Ixenmaier, S.; Toth, E.; Sommer, R.; Mach, R.L.; Linke, R.; Eiler, A. Multiparametric monitoring of microbial faecal pollution reveals the dominance of human contamination along the whole Danube River. Water Res. 2017, 124, 543-555. [CrossRef] [PubMed]

9. Kolarevic, S.; Knezevic-Vukcevic, J.; Paunovic, M.; Tmovic, J.; Gagic, Z.; Vukovic-Gacic, B. The anthropogenic impact on water quality of the river Danube in Serbia: Microbiological analysis and genotoxicity monitoring. Arch. Biol. Sci. 2011, 63, 1209-1217. [CrossRef]

10. AquaNES Deliverable 1.6-Advantages and Limitations, Impact of BF Design, Recommendations for Operators. 2019. Available online: http:/ / www.aquanes-h2020.eu (accessed on 10 February 2019).

11. Benedek, P. New trends in water quality management. Water Sci. Technol. 1982, 14, 47-82. [CrossRef]

12. Grischek, T.; Macheleidt, W.; Nestler, W. River bed specifics and their effect on bank filtration efficiency. In Management of Aquifer Recharge for Sustainability; Dillon, P., Ed.; Balkema Publ.: Lisse, The Netherlands, 2002; pp. 59-64.

13. Grischek, T.; Bartak, R. Riverbed clogging and sustainability of riverbank filtration. Water 2016, 8, 604. [CrossRef]

14. Grischek, T. Management of RBF along the Elbe River. Ph.D. Thesis, Dresden University of Technology, Department of Water Sciences, Dresden, Germany, 2003. (In German)

15. Nagy-Kovács, Z.; László, B.; Fleit, E.; Czichat-Mártonné, K.; Till, G.; Börnick, H.; Adomat, Y.; Grischek, T. Behaviour of organic micropollutants during riverbank filtration at Budapest, Hungary. Water 2018, 10, 1861. [CrossRef]

16. Nagy-Kovács, Z.; László, B.; Simon, E.; Fleit, E. Large scale, long-term operational experiences to sustain secure RBF and well structure remodeling. Water 2018, 10, 1751. [CrossRef]

17. Molnár, Z. Determination of the Production Well Capacities by Modelling; Internal Unpublished Document; Budapest Waterworks: Budapest, Hungary, 2013. (In Hungarian) 
18. Ministry for Environment and Water. Ministerial Decree No. 21/2002. (IV. 25.) on the Operation of Water Supply Systems; Ministry for Environment and Water: Budapest, Hungary, 2002. Available online: https: / / net.jogtar.hu (accessed on 11 February 2019). (In Hungarian)

19. Schoenheinz, D.; Grischek, T. Behavior of dissolved organic carbon during bank filtration under extreme climate conditions. In Riverbank Filtration for Water Security in Desert Countries; Ray, C., Shamrukh, M., Eds.; Springer Science + Business Media B.V.: Dordrecht, The Netherlands, 2011; pp. 51-67.

20. Hoehn, E.; Cirpka, O.A. Assessing residence times of hyporheic ground water in two alluvial flood plains of the Southern Alps using water temperature and tracers. Hydrol. Earth Syst. Sci. 2006, 10, 553-563. [CrossRef]

21. Schmidt, C.K.; Lange, F.T.; Brauch, H.J.; Kühn, W. Experiences with riverbank filtration and infiltration in Germany. In Proceedings of the Int. Symp. Artificial Recharge of Groundwater, Daejon, Korea, 14 November 2003; DVGW-Water Technology Center (TZW): Karlsruhe, Germany, 2003.

22. Grischek, T.; Hiscock, K.M.; Metschies, T.; Dennis, P.; Nestler, W. Factors affecting denitrification during infiltration of river water into a sand and gravel aquifer in Saxony. Water Res. 1998, 32, 450-460. [CrossRef]

23. Henzler, A.F.; Greskowiak, J.; Massmann, G. Seasonality of temperatures and redox zonations during bank filtration-A modeling approach. J. Hydrol. 2016, 535, 282-292. [CrossRef]

24. Ministry for Environment and Water-Ministry of Health-Ministry of Agriculture and Regional Development. Hungarian Drinking Water Guideline: Governmental Decree No. 201/2001. (X. 25) on Water Quality Standards and Monitoring of Drinking Water Quality; Ministry for Environment and Water-Ministry of Health-Ministry of Agriculture and Regional Development: Budapest, Hungary, 2001. Available online: https://net.jogtar.hu (accessed on 11 February 2019). (In Hungarian)

25. Ministry for Environment and Water. Ministerial Decree No. 6/2009 (IV. 14) on the Limits and Measurement Methods Necessary for the Protection of Ground and Ground Water against Contaminations; Ministry for Environment and Water: Budapest, Hungary, 2009. Available online: https://net.jogtar.hu (accessed on 11 February 2019). (In Hungarian)

26. Stuyfzand, P.J. Fate of pollutants during artificial recharge and bank filtration in the Netherlands. In Artificial Recharge of Groundwater, Proceedings of the Third International Symposium on Artificial Recharge of Ground Water, Amsterdam, Netherlands, 21-25 September 1998; Peters, J.H., Ed.; Balkema: Rotterdam, The Netherlands, 1998; pp. 119-125.

27. Partinoudi, V.; Collins, M.R. Assessing RBF reduction/removal mechanisms for microbial and organic DBP precursors. J. AWWA 2007, 99, 61-71. [CrossRef]

28. Hijnen, W.A.M.; Brouwer-Hanzens, A.J.; Charles, K.J.; Medema, G.J. Transport of MS2 phage, Escherichia coli, Clostridium parvum, and Giardia intestinalis in a gravel and a sandy soil. Environ. Sci. Technol. 2005, 39, 7860-7868. [CrossRef] [PubMed]

29. Sandhu, C.; Grischek, T. Riverbank filtration in India-Using ecosystem services to safeguard human health. Wat. Sci. Technol. 2012, 12, 783-790. [CrossRef]

(C) 2019 by the authors. Licensee MDPI, Basel, Switzerland. This article is an open access article distributed under the terms and conditions of the Creative Commons Attribution (CC BY) license (http://creativecommons.org/licenses/by/4.0/). 